\title{
EFFECT OF COMPRESSION RATIO ON PERFORMANCE OF A HYDROGEN BLENDED CNG-DIESEL DUAL FUEL ENGINE
}

\author{
Sridhara Reddy ${ }^{1 *}$, Maheswar Dutta ${ }^{2}$, K.Vijaya Kumar Reddy ${ }^{3}$ \\ ${ }^{1}$ Mechanical Engineering Department, J B Institute of Engineering \& Technology, \\ Moinabad, RR District, Telangana, India. \\ ${ }^{2}$ MNR College of Engineering and Technology, MNR Nagar, Medak District, Telangana, India. \\ ${ }^{3}$ Mechanical Engineering Department, JNTUH, Kukatpally, Hyderabad, Telangana, India. \\ "Corresponding e-mail: sridharkistapur@gmail.com
}

\begin{abstract}
Compression ratios of the engine considerably affect the performance and emission behavior of an engine. The paper discusses about effect of compression ratios on the operating parameters such as brake specific fuel consumption (BSFC), brake specific energy consumption (BSEC), brake thermal efficiency (BTE) and volumetric efficiency on a stationary diesel-CNG dual fuel engine by adding hydrogen fraction as a combustion booster. The exhaust emission behavior of the engine is also presented. Addition of hydrogen in CNG has given better results than diesel-CNG dual fuel operation of the engine. The volumetric efficiency and emissions like NOx are the parameters which needed attention towards this study. The paper presents experimental results and analyzes them.
\end{abstract}

Keywords: Dual fuel engine, Compression ratio, Hydrogen addition and Thermal efficiency.

\section{INTRODUCTION}

Petroleum resources are limited hence the search of alternate fuels for internal combustion engines is continuing all over the world. Several alternative fuels such as vegetable oils, ethanol, methanol, LPG, natural gas, hydrogen have been studied extensively in I.C. Engines since long time ${ }^{1}$. In the exploration of the alternative fuel search Compressed Natural Gas is becoming increasingly important in the I.C. engines application. The use of alternative gaseous fuels in diesel engines is increasing worldwide. Their use is encouraged by the cleaner nature of combustion compared to conventional liquid fuels as well as by their augmented availability at attractive prices. Natural gas has high octane number and therefore is suitable for engines with relatively high compression ratio ${ }^{2}$. There is great prospective for Compressed Natural Gas (CNG) because of its very low emissions. The use of $\mathrm{CNG}$ as an alternative fuel has extensive environmental and economic implications.

\section{Mixing of Hydrogen with CNG}

Hydrocarbon fuels have few draw backs like reduced power output, hard to ignite when operated with lean mixtures. These draw backs can overcome by mixing of hydrogen with hydrocarbon fuels. Its properties like low ignition limits, higher flame speeds make it easy to ignite and reduce misfires when mixed with hydrocarbon fuels ${ }^{3-5}$. Thereby improve in engine performance, reduced fuel consumption and reduced emissions can be realized.

From the studies among various research results, it is learnt about the large number of advantages of $\mathrm{CNG}$ as engine fuel. However, it is also to be noted that, $\mathrm{CNG}$ fuel has few disadvantages which limits the optimum engine performance ${ }^{6}$. The disadvantages of $\mathrm{CNG}$ fuel are lower volumetric efficiency and low flame speed. The poor lean burning ability of CNG leads to the incomplete combustion. The problem of misfire and large cycle to cycle variations which occur are mainly due to the poor lean burn quality of $\mathrm{CNG}^{6,7}$. This lean burn quality can be improved by mixing hydrogen to CNG in some fractions.

The main purpose in blending $\mathrm{H}_{2}$ with $\mathrm{CNG}$ (i.e., $\mathrm{HCNG}$ ) is to improve the lean burn quality of $\mathrm{CNG}^{8}$. The added advantages in using HCNG when compared to dedicated CNG along with other engine fuels such as petrol and diesel are that the infrastructure and operational costs are very much minimized from fully developed CNG infrastructure. Apart from this, it has a readily available $\mathrm{CNG}$ customer base and also most important benefit of reduced emissions such as $\mathrm{NO}_{\mathrm{x}}$ by $50 \%$. This will help HCNG to establish itself and achieve emission standards $\mathrm{NO}_{\mathrm{x}}$ economically ${ }^{9}$.

The experiments were conducted on a car engine mounted on chassis dynamometer. The engine was fuelled with CNG and CNG-hydrogen blends and tested based on European emission regulations. $\mathrm{CO}$ emission found to be reduced by $19 \%$ with hydrogen-CNG blend, but $\mathrm{HC}$ emissions remain unaltered. It was observed that, the NOx emission was found to be increased by $70 \%$. However on energy basis, the SFC was not varied significantly ${ }^{2,10}$.

Several hydrogen-CNG blend ratios between 0 to $50 \%$ were tested on a port injection, turbocharged engine. The tests were conducted for different injection 
timings. The results have revealed that, the MBT timing decreases and thermal efficiency increases by increasing the hydrogen percentage in the blend. It was also revealed a reduction in combustion duration by increase in hydrogen addition. Emissions were reduced by advancing the spark timing, but they were increasing as the load increases ${ }^{11-15}$.

\section{EXPERIMENTAL SET UP}

The experimentation is carried out on a single cylinder, four stroke, water cooled, direct injection (DI) engine. The test set up is developed to carry out set experimentation procedures. The loading facility is made by coupling the engine to an eddy current dynamometer. Fuel supply system is modified to suit the experimental procedure. Air flow into the intake system is measured by U-tube manometer fitted to the test set up. Facility for measuring diesel fuel consumption is provided along with $\mathrm{CNG}$ and hydrogen flow meters. The $\mathrm{CNG}$ and hydrogen storage cylinders are used in the experimentation. The computerized data acquisition facility is provided for the test set up. The exhaust gas recirculation unit is provided in the test set up. The facility to vary the compression ratios of the engine is provided in the test set up. The compression ratios are changed by changing the lever (provided by the manufacturer of the test set up) position which changes the distance between the cylinder head and the piston head. A multi gas analyzer adopted by which exhaust gases like, UBHC (Unburned hydrocarbons), $\mathrm{CO}$ (Carbon monoxide), $\mathrm{CO}_{2}$ (Carbon dioxide) and NOx (Nitric Oxides) are measured and are analyzed. The provisions are also made to measure the temperature at various locations of the test engine. The layout of the experimental set up is shown in the Fig. 1. Photographic View of Computerized Diesel Engine Setup is shown in Fig. 2. The description of the equipment and instrumentation used in the present work is briefly explained below.

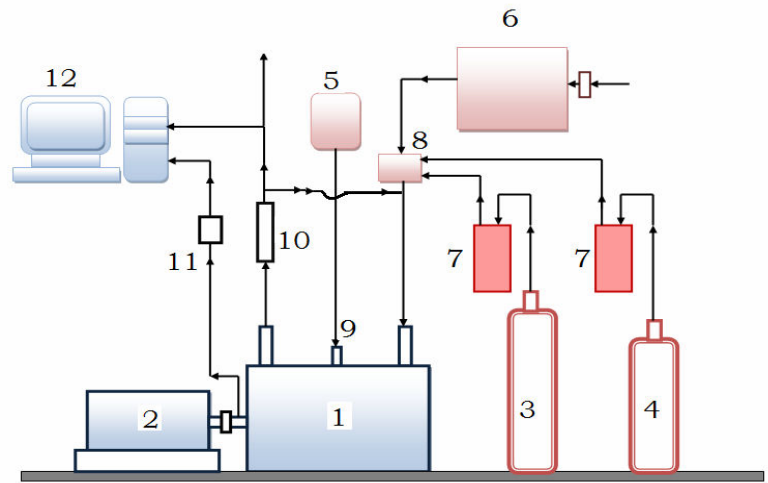

Figure 1. Layout of Experimental Set up.

1. Test Engine

2. Eddy current dynamometer

3. $\mathrm{CNG}$ cylinder

4. Hydrogen cylinder

5. Diesel fuel tank

6. Air surge tank

7. Flame arrestor

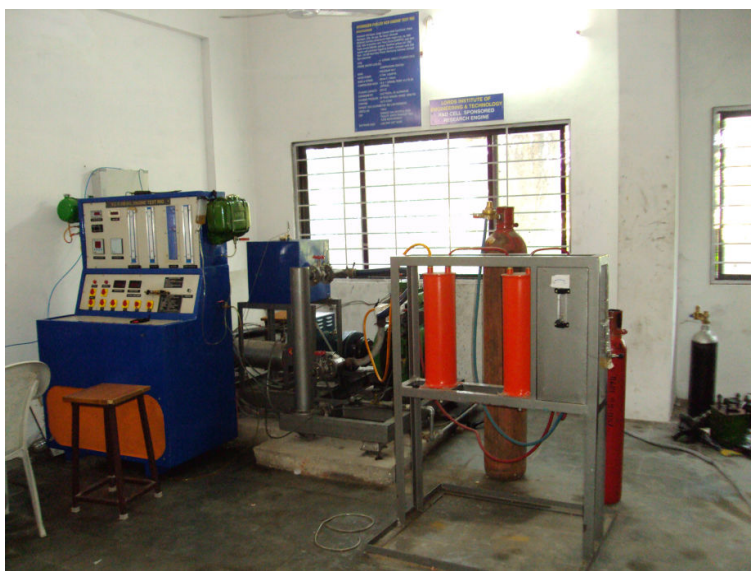

Figure 2. Photographic View of Computerized Diesel Engine Setup.

\section{PERFORMANCE CHARACTERISTICS Brake specific fuel Consumption (BSFC)}

The lower BSFC for required power output is achieved when the combustion efficiency of the fuel is increased. Generally if the compression ratios are increased the combustion efficiency improves and hence the lower specific fuel consumption. The variation of BSFC according to change in compression ratios for different fractions of hydrogen in $\mathrm{CNG}$ mixture is shown in the Fig. 3. It is observed from the figure that the BSFC values are reduced when the compression ratio adopted are increasing. It may be observed from the figure that this reduction in BSFC is up to compression ratio of 16. All the fractions of hydrogen in CNG have shown lowest BSFC at this compression ratio of 16 . But for higher compression ratios the BSFC has shown increased. The improved combustion at higher temperature developed at higher compression ratios are the reasons for better BSFC. Higher compression work required are the reasons which may be quoted for poor performance for further increase of compression ratios. The BSFC values remained lowest at $0.818,0.749,0.766,0.802$ and 0.73 for $5 \%, 10 \%, 15 \%$ and $20 \%$ (of $\mathrm{CNG}$ ) $\mathrm{H}_{2}$ addition respectively at compression ratio of 16.5 compared to 0.854 for diesel $-\mathrm{CNG}$ dual fuel operation.

\section{Brake Specific Energy Consumption (BSEC)}

When different fuel mixtures are used with different heating values to run an engine BSEC becomes a useful parameter to study its performance. BSEC indicates the amount of total fuel energy (diesel and $\mathrm{CNG}$ ) needed to produce $1 \mathrm{~kW}$ power for an hour by the dual fuel engine operation. It means that a lower BSEC indicates higher engine efficiency. The variation of BSFC according to change in compression ratios for different fractions of hydrogen in CNG mixture is shown in the Fig. 4. It is observed that the BSEC values are increased notably when the compression ratio adopted are increased. It may be observed from the figure that this 
increase in BSEC is following same trend of diesel CNG dual fuel operation. All the fractions of hydrogen in $\mathrm{CNG}$ have shown higher BSEC than diesel $-\mathrm{CNG}$ dual fuel operation. The BSEC values recorded as 177900, 179500, 183800, 183900 and $195000 \mathrm{~J} / \mathrm{kW}-\mathrm{h}$ for $5 \%, 10 \%, 15 \%$ and $20 \%$ (of $\mathrm{CNG}$ ) $\mathrm{H}_{2}$ addition respectively at compression ratio of 16.5 compared to $172100 \mathrm{~J} / \mathrm{kW}$-h for diesel-CNG dual fuel operation. It implies that due to use of gaseous fuels ( $\mathrm{CNG}$ and hydrogen) which are having lower density when compared to liquid fuels the energy consumption is more due to pumping losses, as engine has to handle more volume.

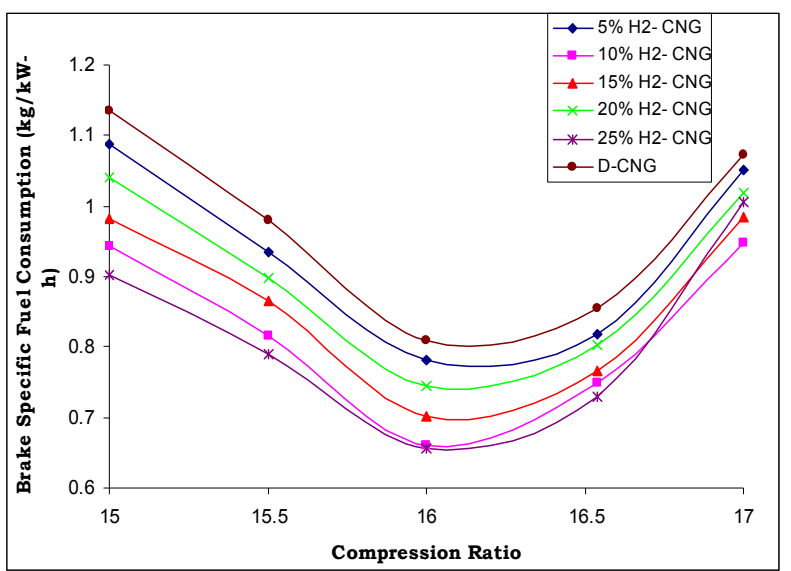

Figure 3. Effect of Compression Ratio on Brake specific fuel Consumption.

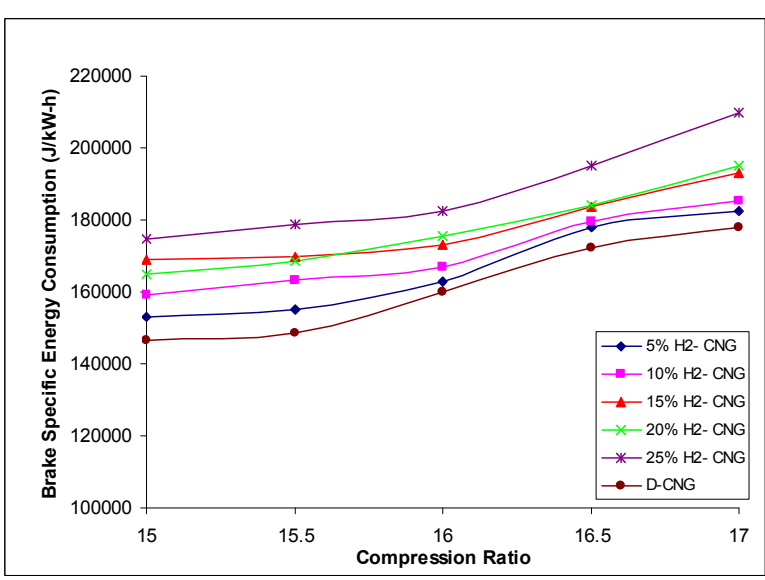

Figure 4. Effect of Compression Ratio on Brakes specific Energy Consumption.

\section{Brake Thermal Efficiency (BTE)}

The variation of BTE according to change in compression ratios for different fractions of hydrogen in CNG mixture is shown in the Fig. 5. Thermal efficiency is improved with the increase in compression ratio. The trend toward higher thermal efficiency with higher compression ratios is maintained for each fraction of hydrogen in CNG fuel. The results show that an increase in compression ratio is more effective in terms of improving thermal efficiency. However, adverse affects such as engine vibration at higher compression ratios are recorded. This is due to higher pressures developed inside the cylinder. All the fractions of hydrogen in $\mathrm{CNG}$ have shown higher brake thermal efficiency than diesel-CNG dual fuel operation. The brake thermal efficiency values recorded as $26.21,26.61,27.64,28.1$ and $28.57 \mathrm{~J} / \mathrm{kW}$-h for $5 \%$, $10 \%, 15 \%$ and $20 \%$ (of $\mathrm{CNG}$ ) $\mathrm{H}_{2}$ addition respectively at compression ratio of 16.5 compared to $25.57 \mathrm{~J} / \mathrm{kW}-\mathrm{h}$ for diesel-CNG dual fuel operation.

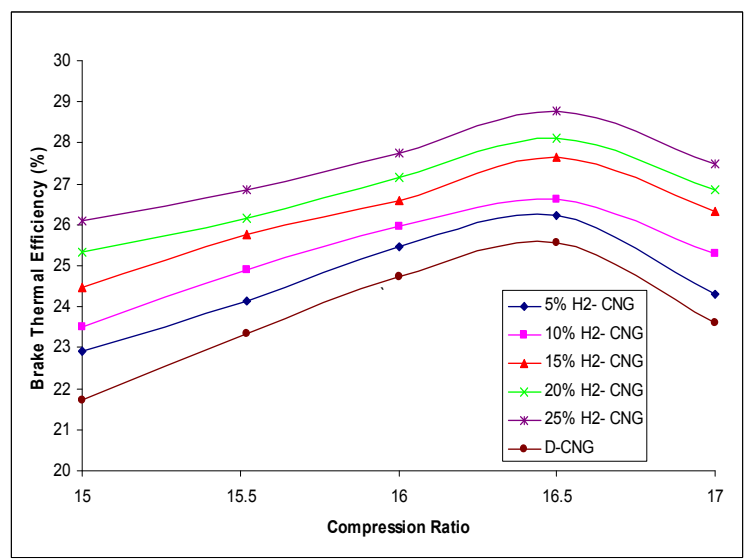

Figure 5. Effect of Compression Ratio on Brake thermal Efficiency.

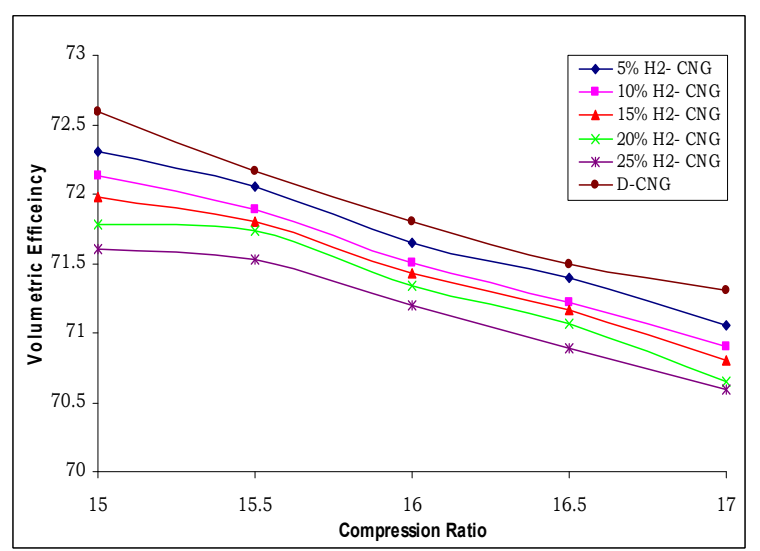

Figure 6. Effect of Compression Ratio on Volumetric Efficiency.

\section{Volumetric Efficiency}

Figure 6 shows the effect of Compression Ratio on volumetric efficiency of the CNG-Diesel dual fuel engine with varying fractions of hydrogen. Volumetric efficiency against different compression ratios is plotted in the figures. From the graphs it is noted that, a small difference between $\mathrm{CNG}$ dual fuel with addition of fractions of hydrogen operation and $\mathrm{CNG}$ dual fuel operation. CNG dual fuel operation has higher volumetric efficiency than dual fuel operation with addition of fractions of hydrogen for all compression 
ratios considered for test.

The graphs show that the volumetric efficiency decreases over CNG dual fuel operation at high CR. Since both CNG and hydrogen are gaseous fuels the density is lower compared to diesel oil, it is obvious that a large amount of CNG is required by the engine to produce the same brake power output. The quantity of fuel inducted into the cylinder at particular temperature is low when compared to pure diesel operation; the compression work required is high for compressing the air and CNG which are inducted simultaneously into the intake manifold. Thus handling large quantity volume of air, CNG and hydrogen mixture leads to lower volumetric efficiency of the engine when compared with CNG-diesel dual fuel mode of operation. The volumetric efficiency values recorded as $71.4,71.22,71.17,71.07$ and $70.89 \%$ for $5 \%, 10 \%$, $15 \%$ and $20 \%$ (of $\mathrm{CNG}$ ) $\mathrm{H}_{2}$ addition respectively at compression ratio of 16.5 compared to $71.49 \%$ for diesel-CNG dual fuel operation.

\section{EXHAUST EMISSIONS}

\section{Nitric Oxides (NOx) Emission}

The Fig. 7 presents the effect of compression ratio on NOx emission in the exhaust. NOx emission against different compression ratios is plotted in the figures. From the graphs it is noted that, a considerable difference in NOx emission exists between CNG dual fuel operation with hydrogen addition and CNG dual fuel operation without hydrogen addition for all compression ratios. Dual fuel operation has given lower NOx emission than diesel-CNG dual fuel operation for all compression ratios. The graphs show that the NOx emission has increased at higher compression ratios. Since the formation of nitric oxide is dependent on operating in-cylinder temperatures and in the CNGdiesel dual fuel mode of the engine the in-cylinder temperatures are lower than operation with hydrogen addition and hence the NOx emission is lower. The NOx emission values recorded as 112.3, 116.3, 121.6, 125.2 and $130.1 \mathrm{ppm}$ for $5 \%, 10 \%, 15 \%$ and $20 \%$ (of CNG) $\mathrm{H}_{2}$ addition respectively at compression ratio of 16.5 compared to $109.3 \mathrm{ppm}$ for diesel -CNG dual fuel operation.

\section{Carbon Monoxide (CO) Emission}

Figure 8 compares the effect of compression ratio on $\mathrm{CO}$ emissions between $\mathrm{CNG}$ dual fuel operation with hydrogen addition and CNG dual fuel operation without hydrogen addition for all compression ratios. $\mathrm{CO}$ emission for different compression ratios is plotted in the figures. A marginal difference in $\mathrm{CO}$ emission exists between them. It is observed that the dual fuel mode with hydrogen addition yield lower $\mathrm{CO}$ emissions for all the compression ratios. This is mainly due to the improved combustion when hydrogen is mixed with CNG fuel. As the compression ratios are increased the $\mathrm{CO}$ emission is recorded lowered for both the engine operation. The CO emission values recorded as 42.6, $41,40,43.5$ and $38.3 \mathrm{~g} / \mathrm{kW}-\mathrm{h}$ for $5 \%, 10 \%, 15 \%$ and $20 \%$ (of $\mathrm{CNG}$ ) $\mathrm{H}_{2}$ addition respectively at compression ratio of 16.5 compared to $109.3 \mathrm{~g} / \mathrm{kW}-\mathrm{h}$ for diesel$\mathrm{CNG}$ dual fuel operation.

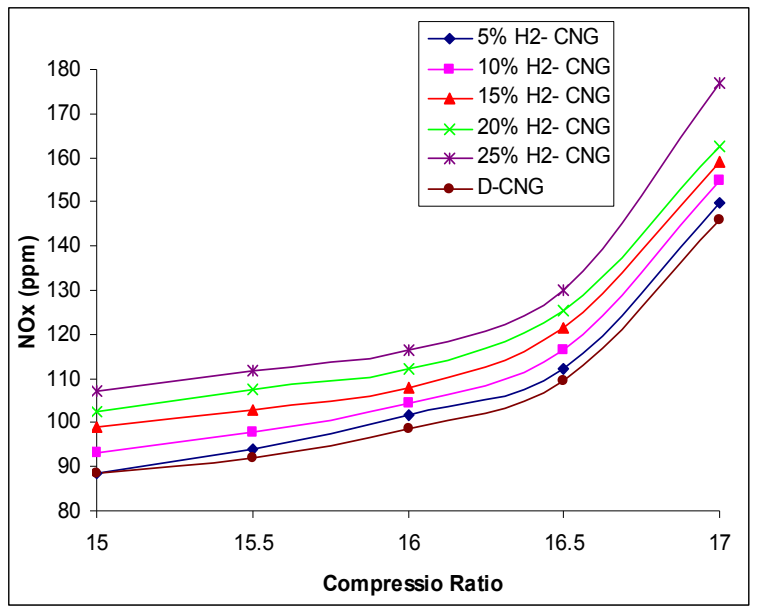

Figure 7. Effect of Compression Ratio on NOx Emission.

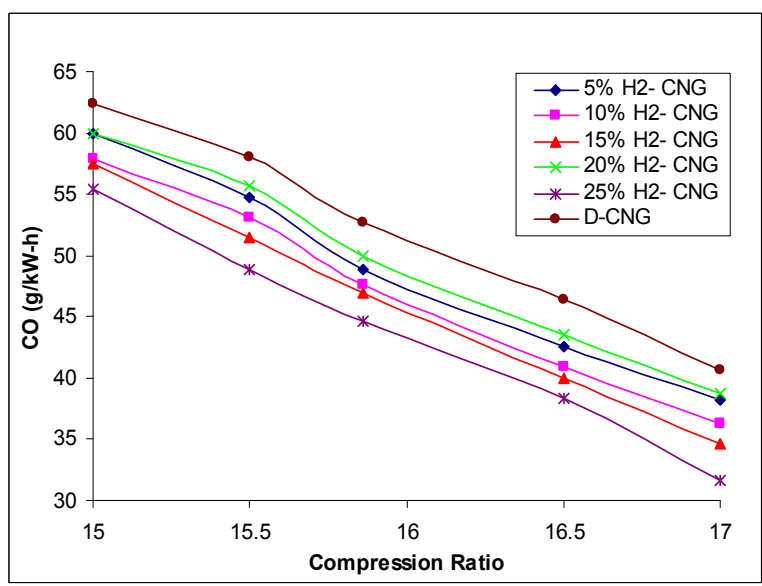

Figure 8. Effect of Compression Ratio on CO Emission.

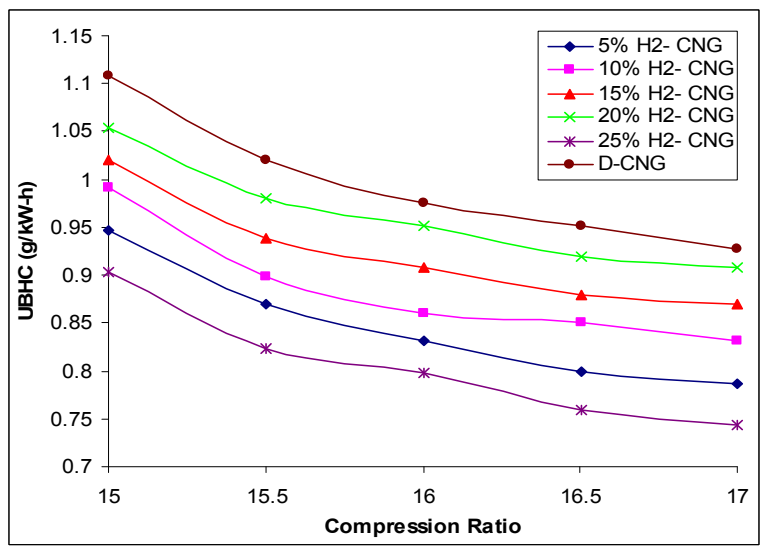

Figure 9. Effect of Compression Ratio on UBHC Emission. 


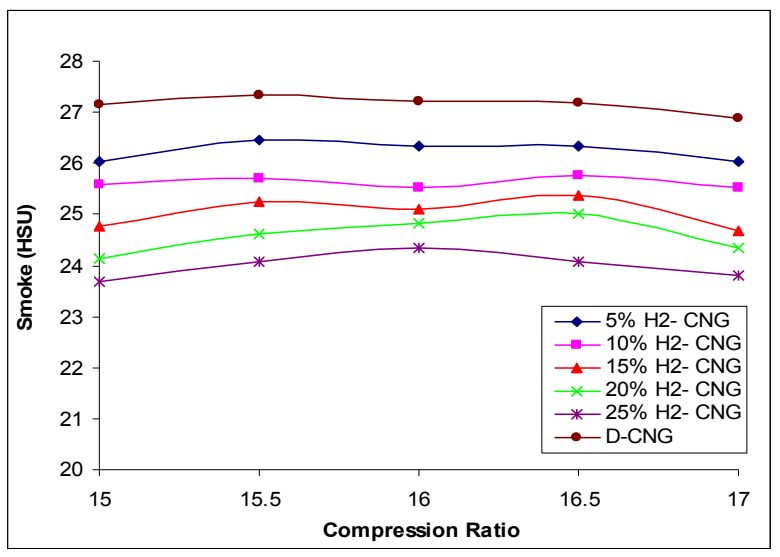

Figure 10. Effect of Compression Ratio on Smoke Opacity.

\section{Unburned Hydrocarbons (UBHC)}

Unburned hydrocarbon emissions represent combustion efficiency of the engine. The UBHC variation in the exhaust emission in relation with the different compression ratios adopted is shown in Fig: 9. The diesel-CNG dual fuel operation with hydrogen addition has emitted marginally lower UBHC emissions than operation of diesel-CNG dual fuel without hydrogen addition. This is attributed by the lower proportion of the escape of gases due to several factors, such as improved burning rate. The UBHC is decreased with increase in compression ratio for both the operations. The lean mixture and exhaust gas temperature of CNG are responsible for less unburned hydrocarbon emission when compared to diesel. The UBHC emission values recorded as $0.8,0.85,0.88,0.92$ and $0.76 \mathrm{~g} / \mathrm{kW}$-h for $5 \%, 10 \%, 15 \%$ and $20 \%$ (of CNG) $\mathrm{H}_{2}$ addition respectively at compression ratio of 16.5 compared to $0.952 \mathrm{~g} / \mathrm{kW}-\mathrm{h}$ for diesel -CNG dual fuel operation.

\section{Smoke opacity}

The deficiency of oxygen locally during the combustion in CI engine leads to formation of smoke. The smoke opacity in the exhaust emission in relation with the different compression ratios adopted is shown in Fig: 10. The figure compares the diesel-CNG dual fuel operation with and without hydrogen addition. A marginal difference in smoke opacity is observed between both the operations. A reduction in smoke opacity with increasing percentage of hydrogen fraction is noted. It is attributed due to cleaner combustion due to addition of hydrogen as it is a non- carbon fuel. The smoke opacity values are recorded as 26.33, 25.78, 25.37, 25 and 24.08 HSU for 5\%, 10\%, 15\% and 20\% (of $\mathrm{CNG}$ ) $\mathrm{H}_{2}$ addition respectively at compression ratio of 16.5 compared to 27.2 HSU for diesel-CNG dual fuel operation.

\section{CONCLUSIONS}

In this work an attempt is made to improve the performance of the $\mathrm{CNG}$ engine by adopting some of the identified areas of engine research. The engine is run on diesel-dual fuel mode. Higher compression ratios are adopted to study the improvement in thermal efficiency. The following conclusions are drawn from the experimental investigations.

- BSFC values are reduced when the compression ratio is increased. All the fractions of hydrogen in CNG have shown lowest BSFC at compression ratio of 16 .

- Thermal efficiency is improved by $15 \%$ with the increase in compression ratio. The results show that an increase in compression ratio is more effective in terms of improving thermal efficiency. However, adverse affects such as engine vibration at higher compression ratios are recorded.

- Dual fuel operation with addition of fractions of hydrogen has lower volumetric efficiency by $10 \%$ than CNG-diesel dual fuel operation for all compression ratios. This is due to lower specific density of the gaseous fuels.

- The NOx emission has increased by $8-10 \%$ at higher compression ratios. Since the formation of nitric oxide is dependent on operating in-cylinder temperatures and in the CNG-diesel dual fuel mode of the engine the in-cylinder temperatures are higher when operated with hydrogen addition. This is due to higher cylinder temperatures and faster burning rate of hydrogen than $\mathrm{CNG}$; hydrogen combustion will enhance the formation of NOx.

- The UBHC, CO emissions decrease with increase in hydrogen addition when compared to CNG-diesel dual fuel operation. The dual fuel mode with hydrogen addition yield lower CO emissions by $8 \%$ for all the compression ratios mainly due to the improved combustion in dual fuel mode and the nature of the CNG fuel. The diesel-CNG dual fuel operation with hydrogen addition has emitted marginally lower UBHC emissions than operation of diesel-CNG dual fuel without hydrogen addition.

\section{REFERENCES}

1. J. Klimstra, 1989, "Carburetor for gaseous fuels on air fuel ratio: homogeneity and flow restriction", SAE paper no. 892147

2. White. C.M., Steeper. R.R., Lutz A.E., 2006, "The hydrogen fueled internal combustion engine- a technical review", Int. J. of Hydrogen Energy, Vol. 31, 1292-1305.

3. Paul. A.S., James S.W., 2005, "Effects of hydrogen content in hydrogen natural-gas fuel mixtures on emissions in a lean-burn IC engines", ASME Fall Conference, pp. 363-371.

4. K. Collier, N. Mulligan, D. Shin, S. Brandon, 2005, "Emission results from the new development of a 
dedicated hydrogen enriched natural gas heavy duty engine", SAE Journal, SAE paper no. 2005-01-0235.

5. Huang Z., Wang J., Liu B., Zeng K., Yu J., Jiang D., 2006, "Combustion Characteristics of a Direct-Injection Engine Fueled with Natural Gas-Hydrogen Mixtures", Energy \& Fuels, Vol. 20, pp 540-546, 2006.

6. Saravanan N., Nagarajan G., Sanjay G., Dhanasekaran C., Kalaiselvan K.M., 2007, "Experimental investigation of hydrogen port fuel injection in DI diesel engine", Int. J. of Hydrogen Energy, Vol. 32, pp. 4071-4080,.

7. Fanhua. M., Yu. W., Haiquan L., Yong L., Junjun W., Shuli Z., 2007, "Experimental study on thermal efficiency and emission characteristics of a lean burn hydrogen enriched natural gas engine", Int. J. of hydrogen energy, Vol. 32, pp. 5067-50758.

8. M. Bysveen, 2007, "Engine characteristics of emissions and performance and using mixtures natural gas and hydrogen”, Energy, Vol. 32, pp. 482-489.

9. Akansu S.Q., Dulger Z., Kahranman N., Veziroglu N.T., 2008, "Internal combustion engines fueled by natural gas-hydrogen mixtures", Int. J. of hydrogen energy, Vol. 29, pp. 1527 - 1539.

10. A. Unich, B. Morrone, A. Mariani, 2009, "The impact of natural gas-hydrogen blends on internal combustion engines performances and emissions", SAE paper No. 2009-24-0102.

11. Lilik G.K., Zhang H, Herreros J.M., Haworth D.C., 2010, "Hydrogen assisted diesel combustion". Int. J. Hydrogen Energy, Vol. 35, pp. 4382-98.

12. E. Ramjee and K.V.K. Reddy, 2011, "Performance analysis of a 4-stroke SI engine using $\mathrm{CNG}$ as an alternative fuel", Indian J. of Science and Technology, Vol. 4 (7), pp 34-44.

13. Singh Y., Vinod S.L., Dilip S., 2012, "Performance and emission studies of direct injection C.I. engine in duel fuel mode (hydrogen-diesel) with EGR", Int. J. of Hydrogen Energy, Vol. 37(4), pp. 3807-3817.

14. Chougule, V., Chhaganlal Vora, K., Suryavanshi, Y., and Gunjegaonkar, D., 2013, "Design and Simulation of 2.5 L Dual Fuel (Diesel-CNG) Engine for Performance Parameters," SAE Technical Paper 201301-2885.

15. E. Ramjee, K.V.K. Reddy and J.S. Kumar, 2013, "Performance and emission characteristics of compression ignition (CI) engine with dual fuel operation (diesel + compressed natural gas (CNG))", J. of Petroleum Technology and Alternative Fuels, Vol. 4(2), pp. 24-29.

\section{APPENDIX - I}

SPECIFICATION OF TEST ENGINE

\begin{tabular}{|l|l|l|}
\hline 1 & Basic Engine & $\begin{array}{l}\text { Single cylinder, direct injection, naturally } \\
\text { aspirated, water cooled, diesel engine }\end{array}$ \\
\hline 2 & Make & Kirloskar India Ltd \\
\hline 3 & Stroke & $110 \mathrm{~mm}$ \\
\hline 4 & Bore & $80 \mathrm{~mm}$ \\
\hline 5 & Displacement volume & $553 \mathrm{cc}$ \\
\hline 6 & Compression Ratio & $\begin{array}{l}16.05: 1 \\
\text { And facility for variable compression ratios from } \\
13.51 \text { to } 20\end{array}$ \\
\hline 7 & Connecting Rod length & $251 \mathrm{~mm}$ \\
\hline 8 & Rated Power & $3.5 \mathrm{~kW}$ \\
\hline 9 & Rated speed & $1500 \mathrm{rpm}$ \\
\hline 10 & Basic Fuel & Diesel - modified to operate with CNG and $\mathrm{H}_{2}$ \\
\hline 11 & Injection Pressure & 200 bar \\
\hline 12 & Inlet valve opening & $8^{0}$ BTDC \\
\hline 13 & Inlet valve closing & $45^{0}$ ATDC \\
\hline 14 & Exhaust valve opening & $45^{0}$ BTDC \\
\hline 15 & Exhaust valve opening & $12^{0}$ ATDC \\
\hline 16 & Injection Timing & 8 degree Crank Angle \\
\hline 17 & Orifice diameter & 20 mm \\
\hline 18 & Calorimeter & Exhaust gas calorimeter \\
\hline 19 & Cooling & Water cooling \\
\hline 20 & Starting & Auto (Switch) start/ hand cranking method \\
\hline 21 & Fuel tank & 15 liter capacity \\
\hline & &
\end{tabular}




\section{APPENDIX - II \\ SPECIFICATIONS OF AUXILIARY INSTRUMENTS}

\begin{tabular}{|c|c|}
\hline 1. Dynamometer & $\begin{array}{l}\text { Make: Kirloskar Brothers Ltd. } \\
\text { Model: KGA-105 } \\
\text { Input: } 240 \text { Volts, } 20.8 \text { AMPS } \\
\text { Output: } 5 \mathrm{kVA} \\
\text { Speed: } 1500 \mathrm{rpm} \\
\text { Rated Power Factor: } 0.8\end{array}$ \\
\hline 2. Pressure Transducer & $\begin{array}{l}\text { Piezo Electric Transducer- KISTLER make, } 0.250 \text { bar with } \\
\text { sensitivity } 1.414 \mathrm{PF} \text {. }\end{array}$ \\
\hline 3. Temperature Sensor & Type RTD- PT100 and thermocouple: Type K \\
\hline 4. Charge Amplifier & KISTLER 5007(100-1.1 K) \\
\hline 5. Smoke Meter & $\begin{array}{l}\text { TI Diesel tune } 113 \text { smoke density tester } \\
\text { Make: Neptune Equipment Pvt. Ltd. } \\
\text { Model: OPAX2000II/DX200P. } \\
\text { Piston displacement: } 330 \mathrm{cc} \\
\text { Stabilization time: } 2 \text { min. } \\
\text { Range: } 0.00-10 \text { ABS 'K' units / } 0 \%-100 \% \text { Bosch units. } \\
\text { Minimum time period: } 30 \text { seconds } \\
\text { Calibrated reading: } 5.0+0.2\end{array}$ \\
\hline 6. Engine Interface & $\begin{array}{l}\text { Thermocouples, Input RTDs, Air flow, Fuel flow, load cell } \\
\text { with 'engine soft' - an engine performance software, add-on- } \\
\text { card of resolution } 12 \text { bit, /16 input, PCI mounting slot. }\end{array}$ \\
\hline
\end{tabular}

